DOI: $10.29295 / 2311-7257-2019-97-3-70-74$

УДК 697.347

\author{
Taraday O. ${ }^{1}$, Sigal O. ${ }^{2}$, Bugai V.1, Pavliuk N. ${ }^{2}$, Shakhnenko Y. ${ }^{1}$ \\ Kharkiv National University of Civil Engineering and Architecture ${ }^{1}$ \\ (Sumska 40, Kharkiv,61002,Ukraine, e-mail: alekst1704@gmail.com; vl.bugai@gmail.com; rotari82@ukr.net; \\ orcid.org/0000-0002-4239-9895; orcid.org/0000-0001-5166-7110) \\ Institute of Engineering Thermophysics of NAS of Ukraine ${ }^{2}$ \\ (Marii Kapnist 2a, Kyiv,03057, Ukraine, e-mail: sigal@engecology.com; nonna.ipe@gmail.com)
}

\title{
RECONSTRUCTION OF HEATING SYSTEMS OF EXISTING RESIDENTIAL BUILDINGS BY MEANS OF EQUIPPING APARTMENT HEATING SYSTEMS WITH HEAT METERS
}

In the article the results of the pilot project on re-equipping of vertical single-pipe heating system of the standard highrise apartment building for horizontal individual heating system, that provides to install a metering device of heating energy consumption in each apartment, are reported. Two variants of individual heating systems are presented. Under the first variant one centralized heating energy source is used, thus the heating system of each apartment is connected directly to the communal part of the system without the heat exchanger. The second variant provides the possibility to install the additional heating energy source in each apartment. Installation of a plate-type heat exchanger and a recycling pump is provided for opportunity of stand alone operation in each apartment. Heat meter availability in each apartment motivates the dwellers to implement energy saving actions that will lead to natural gas saving and reduction of greenhouse gas emission in the environment.

Key words: reconstruction, centralized heating energy source, apartment heating system, vertical single-pipe heating system, horizontal heating system, heat meter.

Introduction. Reduction of natural gas consumption is a strategic orientation of energy security improvement. The significant consumers of natural gas in Ukraine are population and district heating utility enterprises, producing heat energy and heat water supply for population needs (approximately 50\%) [1-6]. According to "Conception of integration of arrangements for sustainable financing of activities on energy saving", approximately $60 \%$ of energy are lost due to ineffective usage of energy resources in the area of housing sector centralized heating, wherewith $98 \%$ comprise apartment blocks [7]. The residential properties of Ukraine has substantial potential of energy saving. $61 \%$ of buildings were built before 1970, during the period of low-price energy sources and lack of quality building materials, resulting in high energy demand of buildings. At the moment the average value of energy intensity of apartment buildings in Ukraine is $264 \mathrm{~kW}$-hour $/ \mathrm{m}^{2}$, that 2-3 times exceeds energy intensity of buildings in EU $\left(90 \mathrm{~kW} \cdot\right.$ hour $\left./ \mathrm{m}^{2}\right)$ [7].

In accordance to the analysis, carried out by the State Agency on Energy Efficiency and Energy Saving of Ukraine, integration of activities on energy saving in the housing sector can provide $47 \%$ of economy of the final energy consumption [8]. According to the Conception [7], $64 \%$ of gas economy can be obtained by means of heat insulation of the residential properties. Without involving of financial assets of the population it is difficult to solve this task.

In accordance to the Law of Ukraine "About fiscal metering of heating energy and water supply" [9], it is necessary to install units of distributing metering of heat energy in the apartment blocks within three years, that each owner can pay his part of consumed heat energy.

However the problem of installation of heat energy residential meters is that more than $80 \%$ of the residential properties of Ukraine were built in the period before 2000 and were equipped with the vertical singlepipe heating system. The structure of such systems completely excludes installation of the heat energy residential meters. Re-equipment of the existing vertical single-pipe heating systems for the horizontal double-pipes individual heating systems will motivate integration of activities on energy saving and lead to significant reduction of heating energy [10-11].

At the moment payment for heating energy is performed by an owner on the basis of 
cost of heating of one square meter of living space, multiplies by the area of the apartment.

The cost of heating of one square meter is determined by the heat energy supplier by means of division of total amount of heat energy, consumed by the house for a month as per values of the communal meter, by total area of all heated apartments and multiplied by cost of one gigacalorie of heat. The cost of heating of common facilities and other communal losses is also included in the heating cost of one square meter of the apartment.

During cost calculation of heating of each apartment, the ration of heat insulation of the apartment and its position in the house (floor, middle or corner ect.) is not taken into consideration. Notwithstanding that the part of apartments of the house is already heat insulated; the payment is calculated equally for all, though heat losses of the heat insulated apartment are less, than of not insulated one.

After re-equipment of the heating system, according to the offered project, the fundamentally new calculation method for heating energy in each apartment is implemented in the house since January 1, 2018.

The calculation principles are the following:

1) the owner of each apartment pays only for the heating energy, that he consumes according to the reading of the meter in his apartment;

2) the owner of each apartment pays cost of heating of common facilities and other commune losses additionally to the reading of the meter in his apartment. Consumption of heating energy for these needs is determined as the difference between readings of commune heating energy meter and amount of readings of apartment heating energy meters, divided by amount of areas of all heated apartments and multiplied by the area of each apartment.

Material and methods. Starting point. In the last three years MRK "Teploenergiia" in cooperation with the scientists of Kharkov National University of Civil Engineering and Architecture has been concerned with modernization of the heating systems of the existing high-rise apartment buildings with the purpose of arrangement of individual regulation of heating consumption and heat energy metering [10-13].

The design solutions on installation of apartment heating with heat energy meters in the existing buildings, developed by the authoring team, have been tested in the largepanel residential house with 32 apartments, 4 floors, 3 communal hallways, a basement and a technical floor, built in 1990. The communal heating system of the house is "standard" vertical, single-pipe, with bottom distribution, i.e. the standard scheme of $60-90$ years (Fig. 1).

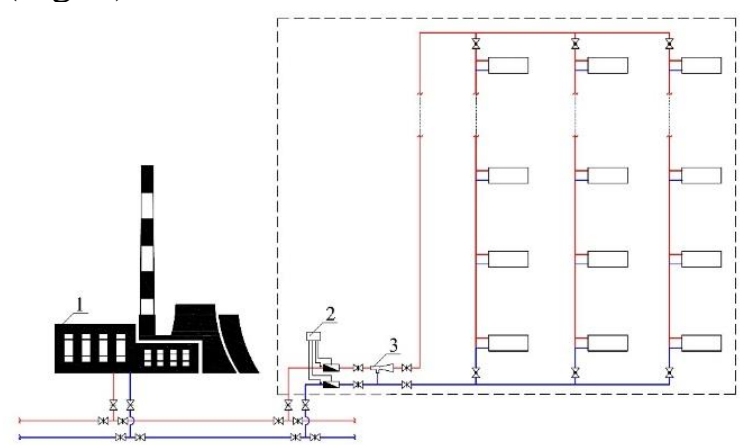

Fig. 1. The existing vertical single-pipe heating system: 1 -centralized heat source (CHP, boiler house); 2 -communal heat meter; 3 - heat distribution station

The communal hallways do not have any heating units. Above-zero temperature in the hallways is maintained by means of heat transmission through apartment inside walls. The house obtains heat energy from the centralized heat supply system. The connection to the centralized heat supply system is carried out by means of the heat distribution station, located in the basement of the building. The communal heat energy meter is installed and properly operates during two heating seasons.

Solution method. After modernization of the heating system, heat energy is supplied from the individual heating plant through the house basement through two steel thermal insulated pipes (delivery and return), which the vertical stand pipes are risen in three communal hallways from. The inlet point in each apartment is carried out from the stand pipes in new individual heating systems.

The heating systems of the apartments are made of propylene pipes, stiffened with touchstone. The thermo shutting down valve with the thermostatic head is installed on 
each heat radiator for opportunity of maintaining the temperature in each apartment that the dwellers need.

The dwellers were proposed two possible variants of individual heating systems.

The first variant of possible individual heating systems has only one centralized heat energy source, therefore the heating system of each apartment is directly connected to the communal part of the system without the heat exchanger (Fig. 2a).

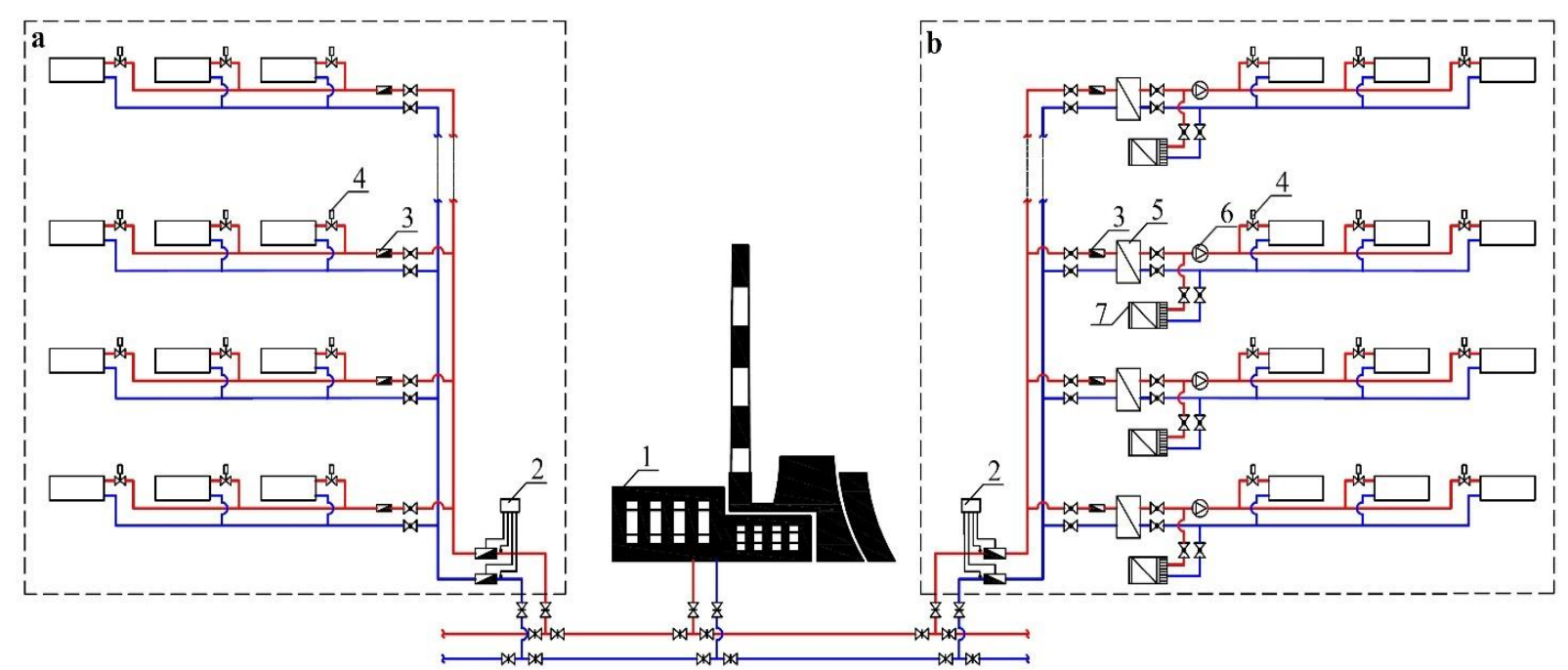

The second variant provides the possibility of installation of the additional heat energy source (electric boiler, solar unit, heat pump and others) in each apartment. Such solution allows to switch on and off the heating at any time, independently from the central heating energy source. Installation of a platetype heat exchanger and a recycling pump is provided for opportunity of stand alone operation in each apartment (Fig. 2b).

Fig. 2. Diagram of individual decentralization ( $a$ - with direct connection of apartment heating systems; $b$ - with individual connection through apartment heat exchangers): 1 - centralized heat source (CHP, boiler); 2 -communal heat meter; 3 -apartment heat meter; 4 -thermostat controller; 5 -plate-type heat exchanger; 6-recycling pump; 7 - electric boiler

Obtained results analysis. The project on re-equipment of the old single-pipe heating system for the individual system with the custom heat meters is realized in Ukraine for the first time. Within the scope of works, the design, completing, construction and installation and adjustment works on modernization of heating systems of any residential house by means of installation of the individual heating systems with revenue heat energy meters in each apartment were carried out.

Installation of shut-off valves and thermostat controllers on each heating unit completed with installation of the individual meter provides conditions for optimizing control and consumption of heat energy, providing energy and finances saving.

The average cost of carrying out of modernization of one apartment of the observed house is 940 Euro, and the budget (economy) variant without replacement of the heating units and installation of thermostat controllers will comprise 550 Euro. In Tabl. 1 the costs of installation of high-quality and the heat energy meter of the corresponding price, replacement of all heating units for modern ones, installation of the thermostat controller in front of each heating unit, laying of new pipes and fittings in the apartments are indicated.

The result of such reconstruction is complete refusal from the existing singlepipe vertical heating system and its replacement with the individual horizontal doublepipes heating systems with the heat energy meters. 
Table 1 - Costs for complete reconstruction of the standard residential house with 32 apartments (in Euro*)

\begin{tabular}{|c|c|c|c|c|c|c|c|c|c|c|c|c|c|c|c|c|}
\hline \multirow[b]{2}{*}{$\begin{array}{l}\text { Ser. } \\
\text { No. }\end{array}$} & \multirow[b]{2}{*}{$\begin{array}{l}\text { Apart- } \\
\text { ment ti- } \\
\text { tle }\end{array}$} & \multirow[b]{2}{*}{ 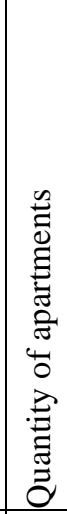 } & \multicolumn{14}{|c|}{$\begin{array}{l}\text { Costs for re-equipment of the heating system of apartments considering the communal costs, related to } \\
\text { one apartment (Euro) }\end{array}$} \\
\hline & & & 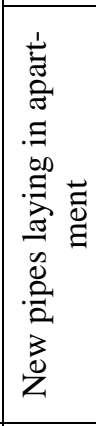 & 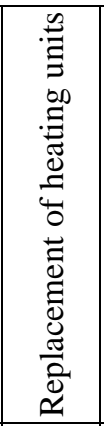 & 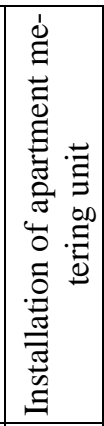 & 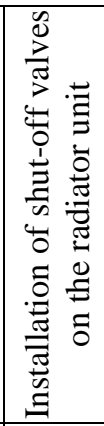 & 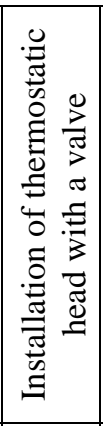 & 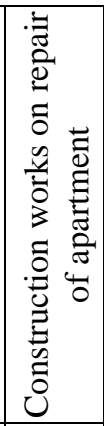 & 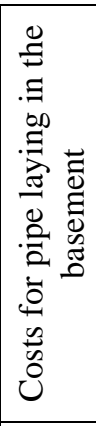 & $\begin{array}{l}\tilde{0} \\
0 \\
0 \\
0 \\
0 \\
0 \\
0 \\
0 \\
0 \\
0 \\
0 \\
0 \\
0 \\
0 \\
0 \\
0 \\
0 \\
0 \\
0\end{array}$ & 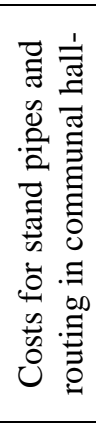 & 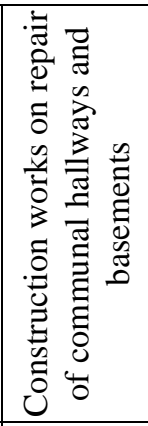 & 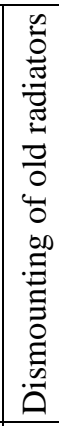 & 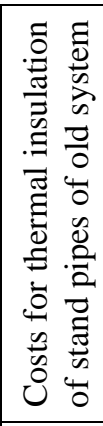 & 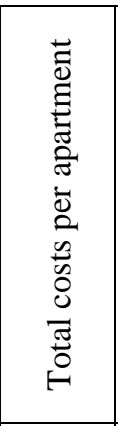 & 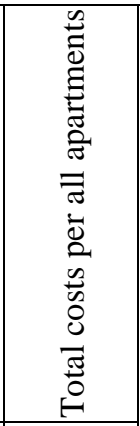 \\
\hline 1 & 2 & 3 & 4 & 5 & 6 & 7 & 8 & 9 & 10 & 11 & 12 & 13 & 14 & 15 & 16 & 17 \\
\hline 1 & $\begin{array}{l}\text { One- } \\
\text { room }\end{array}$ & 8 & 140,0 & 73,3 & 286,6 & 8,7 & 82,7 & 13,3 & 10,0 & 21,0 & 133,3 & 10,0 & 3,3 & 15,0 & 797,2 & 6377,8 \\
\hline 2 & $\begin{array}{l}\text { Two- } \\
\text { room }\end{array}$ & 8 & 226,6 & 110,0 & 286,6 & 13,3 & 124,0 & 16,7 & 10,0 & 21,0 & 36,7 & 10,0 & 5,0 & 15,0 & 874,9 & 6999,0 \\
\hline 3 & $\begin{array}{l}\text { Three- } \\
\text { room }\end{array}$ & 12 & 250,0 & 146,6 & 286,6 & 17,3 & 165,3 & 20,0 & 10,0 & 21,0 & 76,7 & 10,0 & 6,7 & 15,0 & 1025,2 & 12302,3 \\
\hline 4 & $\begin{array}{l}\text { Four- } \\
\text { room }\end{array}$ & 4 & 260,0 & 183,3 & 286,6 & 21,7 & 206,6 & 23,3 & 10,0 & 21,0 & 86,7 & 10,0 & 8,3 & 15,0 & 1132,5 & 4530,0 \\
\hline 5 & $\begin{array}{l}\text { Total in } \\
\text { the } \\
\text { house }\end{array}$ & 32 & & & & & & & & & & & & & & 30209,1 \\
\hline
\end{tabular}

In the calculation of the payback period, we have every right to count out the costs for new pipeline laying under installation of the horizontal heating system, as all existing heating systems of the past century almost served out their statutory service life and under retrofitting, they are subject to complete replacement.

\section{Conclusions.}

1. The developed scheme of the heating supply (heating system) allowed fulfilling revenue metering of heating medium supply directly in the apartment, both under centralized heating supply system and under combination of centralized and decentralized system of heat medium supply.

2. Reconstruction of heating system actually resulted in reduction of heat energy consumption by the apartment more than $30 \%$ for the heating season, that in monetary value for the "average" apartment is approximately 100,0 Euro/year or $25-35 \%$ of costs for heating supply of the dwellers.

3. The payback period of investments will comprise 3-4 years.

4. Availability of the individual heat metering device is significant motivation for fulfillment of external heat insulation of the apartment and corresponding reduction 20$30 \%$ of greenhouse gas emission in the environment.

\section{REFERENCES:}

1. Долінський А.А., Сігал О.І., Кучин Г.П., Корінчук К.О., Логвин В.О. Перспективи зниження витрат природного газу в системах центрального теплопостачання України. Промислова теплотехніка, 2014. Т. 36, № 6. C. 5- 11.

2. Долінський А.А., Басок Б.І., Базєєв Є.Т., Кучин Г.П. Основні положення концепції Національної стратегії теплозабезпечення населених пунктів України. Промислова теплотехніка, 2009. Т. 31. № 4. С. 68-77.

3. Патон Б.С., Долінський А.А., Геєць В.М., Кухар В.П., Басок Б.І., Базєєв Є.Т., Подолець Р.3. Пріоритети національної стратегії теплозабезпечення населених пунктів України. Вісник НАН Украӥни. 2014. № 9. С. 29-47.

4. Тарадай А.М., Яременко М.А., Чернокрылюк В.В., Есин Е.С. Основные направления модернизации систем теплоснабжения для решения задачи снижения потребления природного газа в Украине. Науковий вісник будівництва. Харків: ХНУБА, ХОТВ АБУ. 2014. Вип.77. С. 120-123.

5. Semikolenova Y., Pierce L., Hankinson D. Modernization of the district heating systems in 
Ukraine: heat metering and consumption-based billing. 2012. URL: https://openknowledge. worldbank.org/bitstream/handle/10986/17147/6 49890ESW0P1220M0UkraineDHreportENG.pd $\mathrm{f}$ ?sequence $=1$

6. Білодід В.Д., Куц Г.О. Аналіз стану систем теплопостачання України та теплогенеруючих джерел за 2007-2010 роки. Проблеми загальної енергетики. 2012. № 4. С. 29-37.

7. Розпорядження Кабінету Міністрів України від 13 липня 2016 р. № 489-р «Про схвалення Кониепиії впровадження механізмів стабільного фінансування заходів з енергоефективності (створення Фонду енергоефективноcmi)». URL: https://www.kmu.gov.ua/ua/ npas/249189954.

8. Заключний проект з розрахунку циілі з енергоефективності на період до 2020 р. (включаючи перспективу до 2030 р.). URL: http://saee.gov.ua/sites/default/files/Draft\%20E ED\%20Targets_Final.pdf.

9. Закон України від 22.06.2017 №2119-VIII «Про комериійний облік теплової енергї̈ та водопостачання». URL: http://zakon2.rada. gov.ua/laws/show/2119-19/page.

10. Тарадай А. М. и др. Централизованное поквартирное отопление с регулированием и коммерческим учетом отпуска тепла. Вентилячія, освітлення та теплогазопостачання. 2010. №. 14. C. 36-42.

11. Яременко М.А. Раціональні режими відпуску теплоти централізованими та автономними джерелами при їх сумісному функціонуванні: дис. ... канд. техн. наук: спец. 05.23.03 - вентиляція, освітлення та теплогазопостачання. Харків: ХНУБА, 2012. 155 с.

12. Тарадай А. М., Бугай В.С., Шахненко Е.Д., Фомич С.В. Поквартирная децентрализация систем теплоснабжения существующих многоэтажных жилых зданий на базе действующих источников теплоты. Науковий вісник будівництвва. 2017. Т. 89. № 3. С. 166-172.

13. Тарадай А.М., Ланцберг Н.Г., Бугай В.С., Фомич С.В. Математическое обоснование подхода к оплате за услуги теплоснабжения при термомодернизации жилых зданий. Енергоефективність в будівництві та архітектурі. К.: КНУБА, 2017. Вип. 9. С. 232-237.

14. Національний банк України: URL: https://bank.gov.ua.

Тарадай О.М., Сігал О.І., Бугай В.С., Павлюк Н.Ю., Шахненко Є.Д. РЕКОНСТРУКЦІЯ СИСТЕМ ОПАЛЕННЯ В ІСНУЮЧИХ ЖИТЛОВИХ БУДИНКАХ ШЛЯХОМ ОБЛАДНАННЯ КВАРТИРНИХ СИСТЕМ ОПАЛЕННЯ 3 ЛІЧИЛЬНИКАМИ ТЕПЛА. У статті наведені результати пілотного проекту з переобладнання вертикальної однотрубної системи опалення типового багатоповерхового житлового будинку на горизонтальну поквартирну систему опалення, яка дає можливість встановлення у кожній квартирі приладів обліку споживання теплової енергії. Розглядаються два варіанти поквартирних систем опалення. За першого варіанта використовується одне централізоване джерело теплової енергії, тому система опалення кожної квартири підключається до загальнобудинкової частини системи безпосередньо, без теплообмінника. Другий варіант передбачає можливість встановлення у кожній квартирі додаткового джерела теплової енергії. Для можливості незалежного функціонування передбачена установка пластинчастого теплообмінника і циркуляційного насоса в кожній квартирній системі. Наявність приладу обліку теплової енергії в кожній квартирі стимулює мешканців впроваджувати енергозберігаючі заходи, що призведе до економії природного газу і до скорочення викидів парникових газів у навколишнє середовище.

Ключові слова: реконструкція, централізоване джерело теплової енергії, квартирна система опалення, вертикальна однотрубна система опалення, горизонтальна система опалення, теплолічильник.

Тарадай А.М., Сигал А.И., Бугай В.С., Павлюк Н.Ю., Шахненко Е.Д. РЕКОНСТРУКЦИЯ СИСТЕМ ОТОПЛЕНИЯ В СУЩЕСТВУЮЩИХ ЖИЛЫХ ЗДАНИЯХ ПУТЕМ ОБОРУДОВАНИЯ КВАРТИРНЫХ СИСТЕМ ОТОПЛЕНИЯ С СЧЕТЧИКАМИ ТЕПЛА. В статье приведенЫ результаты пилотного проекта по переоборудованию вертикальной однотрубной системы отопления типового многоэтажного жилого здания на горизонтальную поквартирную систему отопления, которая дает возможность установки в каждой квартире приборов учета потребления тепловой энергии. Рассматриваются два варианта поквартирных систем отопления. При первом варианте используется один централизованный источник тепловой энергии, поэтому система отопления каждой квартиры подключается к общедомовой части системы напрямую без теплообменника. Второй вариант предусматривает возможность установки в каждой квартире дополнительного источника тепловой энергии. Для возможности независимого функционирования предусмотрена установка пластинчатого теплообменника и циркуляционного насоса в каждой квартирной системе. Наличие прибора учета тепловой энергии в каждой квартире стимулирует жильцов внедрять энергосберегающие мероприятия, что приведет к экономии природного газа и к сокращению выбросов парниковых газов в окружающую среду.

Ключевые слова: реконструкция, централизованный источник тепловой энергии, квартирная система отопления, вертикальная однотрубная система отопления, горизонтальная система отопления, теплосчетчик. 